Александар М. Милановић

Универзитет у Београду

Филолошки факултет

https://doi.org/10.18485/ai_beckovic.2019.ch11

821.163.41.09-1 Бећковић М.

$811.163 .41 ' 373$

\title{
ОБЕЛЕЖЕНА ЛЕКСИКА У БЕЋКОВИЋЕВОЈ ЗБИРЦИ ХЛЕБА И ЈЕЗИКА
}

У раду се анализирају фреквенција и функције обележене лексике (дијалектизама, локализама, колоквијализама, вулгаризама и неологизама) у Бећковићевој збирци Хлеба и језика. У анализи се полази од одређивања позиције лирског субјекта, готово наратора или приповедача, у односу на његов песнички исказ, а међу различитим типовима маркиране лексике покушавају се установити корелације.

Кључне речи: маркираност, песнички језик, песничка лексика, симбол, кумулација, дијалектизам, колоквијализам, локализам, вулгаризам, неологизам

Чоек је језик / А језик кућа и кућиште Матија Бећковић

1. Лексичка обележеност исказа поетског субјекта и јунака. О Бећковићевој књизи Хлеба и језика писало се из угла стилистике ређе но о другима, нарочито у односу на оне које су јој претходиле. ${ }^{1}$ Критика је у њој запазила стилске функције устаљених конструкција, а мању је пажњу

1 Примере у овом раду наводићемо према издању из „Сабраних дела у девет књига": Хлеба и језика, Београд: Српска књижевна задруга, 2003. 
посветила специфичностима лексике. А управо књига Хлеба и језика нуди богат лексички материјал који сведочи о занимљивости и иновативности Бећковићевог поетског поступка јер је песник у њој проговорио различитим гласовима, крећући се на линији од дијалекта, као у песмама које ћемо у раду анализирати у тачки 2, до чистога стандардног језика, окупљеним у IX целини: „Трорука чудотворка”, „Прича о Светом Сави”, „Огледало”, „Пас” и „Бодеж”. „Привучен могућностима мултипликације песничког језика и његовим трансформацијама" (Палавестра 2012: 232) Бећковић је остао током целокупног стваралаштва, а језичко-стилске промене су у доброј мери узроковане променама перспективе, углова из којих лирски субјекат посматра свет, било као микро- или макрокосмос.

Ко све проговара у Бећковићевој књизи Хлеба и језика? Поетски субјекат је од песме до песме посве различит, и та је диференцијалција стилски изразито наглашена кроз индивидуализованост израза. Тамо где је израз поетског ја удаљенији од стандардног језика готово по правилу препознајемо специфичности израза „поетскога $\mathcal{м и ” ~ с а с в и м ~ к о н к р е т н е ~ л о к а л н е ~ с р е д и н е ~ с р е - ~}$ дине, односно ровачког говора, као и у поемама Рече ми један чоек, Међа Вука Манитога и Леле и куку. И таквом изразу овде најлепше сведочи поетско ја у песмама „Писмо”, „Бе рече Јапан”, „Крушка”, „Ниси ти више мали” или „Распра пред никшићким манастиром има ли под небом више богомоље”. Позиција и статус поетског субјекта различити су, а понегде их има и више у једној песми. На пример, у песми „Који је оно, мајко?” прати се разговор између мајке и сина, а у песми „Стид” расправа две жене на суду. До увођења другог гласа стиже се и цитирањем, па се тако у песми „Огледало” дискретно укрштају искази поетског ја, ослободиоца Београда, и свештеника којег у песми цитира: Када смо ослободили Београд / Одведоше нас у цркву Ружицу / Да се приче- 
стимо / Али поп не да причесну ужицу / Док се не исповедимо. // Мене упита / Јеси ли убио / Јесам / Рекох / A он / Војниче што си то учинио? (108). И у песми „Јеја” лирски субјекат цитира мајчине речи, а њихова веродостојност посебно је истакнута исказом датим у загради: Ето какав је био / Ни он није био најгори (Тако је ову причу почињала моја мати) (80).

Вероватно су језичко-стилски најиздиференциранији искази у песми „Краљ Петар II”, у којој поред поетског субјекта проговарају још и краљ Петар II, затим капетан Лазаревић, чији се статус јасно одређује напоменом да је био „краљев пратилац”, те емигрант Јоксим Смоловић, којег капетан описује следећим речима: Поштен чоек а већ пропао / Пропио се и помео / Лутајући по белом свету / С вером у Бога / Краља и Отаџбину (88). Поетско jа у читавој песми „изговара” само једну реченицу, стилски изразито необележену: Каже његов пратилац / Капетан Лазаревић (88). Песму исказом истргнутим из „разговора” са поетским субјектом започиње капетан, који му препричава занимљиву анегдоту. У њој, пак, „проговарају” и емигрант и, коначно, са̂м краљ. Исказ несрећног емигранта, пуног једа, обележен је активирањем пејоратива (пробисвет) и одговарајућим разговорним фразеологизмом (вући на леђима). Његов исказ капетан дефинише као закукаване: Чим нас је умотрио / Поче да закукава / Ко ти је тај пробисвет / Увек нађеш некога да те пљачка / И да га вучеш на леђима / Добри мој капетане Лазаревићу (89). Не препознајући краља у емиграцији, Јоксим му се обраћа и на енглеском, прелазећи потом на разговорни српски језик (ајде), недостојан обраћања краљу и на нивоу конвенције и граматике друштвеног статуса, будући да употребљава заменицу ти: А Јоксим стаде пред Његово Величанство / What's your name / Како ти је име / Пита он свога краља / Ајде реци колико си му узео (89). Јоксимов „пометени” исказ и даље подразу- 
мева мешавину разговорног српског и енглеског језика, коју капетан, а кроз њега и лирски субјект, јасно мотивише: Ти си мени однекуд познат / Као да сам те негде и раније гледао / Каже он ономе коме се заклео / И за којим је лутао по белом свету / С вером у Бога / Краља и Отаџбину / Who are you / Ко си ти / Потроши Јоксим и друго питање / Које су и њему најчешће постављали / А само то је и знао од енглеског језика (90). Краљев одговор изречен је „сабраним гласом” и „чисто српски”, што се може схватити буквално, али и метафорично: Краљ на то сабраним гласом / И чисто српски одговори / Иди у Валдорф Асторију / И питај / Је ли тамо Петар II Карађорђевић / Краљ Срба Хрвата и Словенаца / Син и унук краљев / И чукунунук Вождов // Па ако је он тамо // Ја више не знам ко сам.

Из наведених примера се види да се и поетски (лирски и епски) субјект и поетски (лирски и епски) јунаци у Бећковићевој поезији приближавају улози наратора, приповедача. ${ }^{2}$ У основи Бећковићевих песама у књизи Хлеба и језика је прича, догађај, а у стилском грађењу различитих исказа препознајемо и технику сказа, казивања, као и у претходним књигама (Делић 2012: 23).

2. Дијалектизми као речи-симболи и средство објективизације. Статус најзначајнијег творца дијалекатске поезије Бећковић је заслужио већ својим поемама из 70-их година (Милановић 2010), ${ }^{3}$ а потврдио га новијим, те су поједине лексеме у свом дијалекатском руху вре-

2 У ровачким поемама Јован Делић (2012: 23) препознаје „казивача, сиже, нарацију, јунака". Појам казивач користи и Радивоје Микић (2012: 87): „У поемама Матије Бећковића се сусрећемо са врло сложеним изражајним средствима и врло различитим настојањима да се казивачу и ономе што говори обезбеди ауторитет".

3 Стремљење ка дијалекту у књижевности, не само српској, Александар Петров (2012: 484) окарактерисао је као „обнову регионализма". 
меном постале и својеврсни поетски бећковићизми. Облици попут чоек или ћерати директно су се из Бећковићеве поезије, и наслова његових књига, одомаћили и у српском новинарству, чак и у свакодневној комуникацији. Не чуди стога што се као средство објективизације дијалектизми појављују и у књизи Хлеба и језика, овај пут са функцијом да стишаније, мање наглашено но у дијалекатским поемама, локализују нове поетске субјекте и јунаке који активирају ове лексичке форме. ${ }^{4}$

2.1. Именица чоек употребљена је чак 18 пута. Чује се у различитим гласовима: Чоек му је дао 10, Кад изби чоек с оне стране 12 , Зауставио се чоек на окуци 12, Виде познат им чоек 13, Не гради чоек кућу / Него кућа чоека / Чоек је језик 22, То је ништа чоек 23 , Нећеш га слушати ако си чоек 30, Ни чоек без чоека 32 , И чоек је чоек / Ако може сам 33 , Дај више буди чоек 59, Обуци се ко чоек 60, Али је био рођени чоек 63, Дај више буди чоек 64, Чоек на једну воду 81, И не лајеш као чоек 97, А не чоек причао и измишљао 97, Све док наш чоек из магле не избије 99. Облик ове именице постаје средство локализације, али и прецизирања друштвеног положаја, у исказу поменутог капетана Лазаревића из песме „Краљ Петар II”. Наиме, док је емигрант Јоксим Новић описан кроз активирање дијалекатског фонетског облика именице: Поштен чоек а већ пропао (88), краљ је у капетановом исказу завредео стандардну, друштвено престижнију форму: Најбољи човек на свету / Био је краљ Петар II (88), Био је то најбољи човек на свету (89).

Симболика речи чоек постаје додатно наглашена извођењем апстрактне именице чоештво, која веома прецизно описује друштвене идеале локалне средине, као у песми „Јеја”, нарочито када је дата у напоредном

4 Марко Радуловић (2012: 205) прецизно запажа да „поред улоге поетског субјекта, дијалекатски језик се у Бећковићевој поезији јавља и као објективизовани говор лирског јунака". 
низу сродних појмова: Женског Риства / И Ристовства / Женског чојства / И чоештва (82).

2.2. Нестандардни облици са јекавским јотовањем у групи /dj/, раширени по читавој јекавској територији, чести су и у овој Бећковићевој књизи. Будући да у њој жели посве другачији ефекат но у претходној књизи Ћераћемо се још (уп. Милановић 2016а), међу примерима, нимало случајно, нема примера са јотовањем у групи /tj/ - глагола ћерати, а облике са јекавским јотовањем препознајемо у пет лексема: ђе (Да се има ђе 19, Ђе рече Јапан... 27, Ђе ти је капа 60, Ђе су ти врсници 61, Ђе сте ви мрдали 91), неђе (Отићи неђе 19); ђевојка (И покаже ђевојкама / Свога јединка 49, И уцвелим ђевојке 51, Невесело погледну на ђевојке и крвнике 51, Да се не обрукам пред јатком и ђевојкама 52, Да не виде крвници и ђевојке 54, Јатка је још погледивала на крвнике и ђевојке 55), ђеца (Ђеца се не милују 62, И ђецу изродио 64, Знаш колико су те ђеца пожељела 74, Свето двоје / Ђецо оче 82) и ђед (Ђед ти је млађи био 63, И постао ђед 65). ${ }^{5}$

У песми „Крушка”, писаној стандардизованом екавицом, појављује се, наспрам дијалекатске ијекавске форме ђе, и стандардизована фонетска форма где, а не разговорна форма де: Где уз воћке има више млатаца него грана / Где се камен баца само на родно дрво / Где је све уназађено и унесрећено / Где ништа не цвета (44).

2.3. Бећковићев песнички језик благо маркирају широко распрострањени дијалектизми и колоквијализми који се од лексема из стандардног језика разликују само по одсуству фонеме /h/: Да размане по његовски (24), А и да оће / Не би имао шта (25), Испадало је да се врзма око апса (78), Није се бојала да ће је апсити (78). Понегде активирање дијалекатских облика прати кон-

5 Облик ђе стилски боји и наслов данас већ познате песме: „Ђе рече Јапан" (27). 
куренција нормираних форми, па тако у песми „Ђе рече Јапан” лирски јунак, сасвим немотивисано, напоредо употребљава речи са фонемом /h/ и без ње: а) Радо бих те слушао / Нема збора / Само кад бих могао (28), А да их питаш шта је ко рекао (31), Нико ме не нагони него ја хоћу (31), И да хоћеш да причаш причао би (33), Све хоћу да ти кажем (33); б) Греота је да говориш (29), По једнога уватим (32), Само лади уста и климај главом (33).

2.4. Сасвим ретко Бећковић активира дијалекатско-колоквијалну фонетску форму лексике са широко распрострањеном асимилацијом и контракцијом вокала / aо/: Ко на јави су га гледали (13), По годину сам себе наговаро (29), Кад је осто сироче (63). Наспрам ових форми стоје фреквентнији облици са очуваном вокалском групом: А један је гледао (9), Написао је (11), И све тако стајао и гледао (13), Сваког питао чији си / Сваког помиловао (13), Обећавао да ће поново доћи (13), Кад сам га угледао (14), Именом бих га зовнуо / И по себи познао (15) итд. ${ }^{6}$

2.5. Само један, али веома карактеристичан, морфолошки дијалектизам представља форма датива једнине личних заменица у песми снажног емотивног набоја „Мушка тужбалица": Жао мене / Тебе мога / Мени твоме / Куку мене / покојноме (82). Само условно овде би се могао сврстати и дужи облик множине именице облак, са инфиксом -ов-: облакови (Загледао литице и пећине / Магле и облакове 12-13).

3. Локализми као средство актуелизације. Од дијалектизама и колоквијализама теоријско-методолошки није лако раздвојити локализме, односно покрајинске лексичке форме. ${ }^{7}$ У овој Бећковићевој књизи има их

6 Посве локално звучи и форма традиционалног поздрава пренета у Бећковићеву поезију у песми „Долазак”: Помага Бог / Бог ти помогао (14).

7 Под локализмима подразумевамо део лексикона стандардног језика који се у нормативним речницима наводе са квалификатором „покр.. 
много, увек у функцији актуелизације, што је и служба дијалектизама. Неретко су примери из ових двеју лексичких група дати и напоредо у истом Бећковићевом стиху, који стилски маркирају на сличан начин, само са различитим нормативистичким предзнаком - што је за песнички језик ирелевантно. Тако у Бећковићевој песми „Који је оно, мајко" стилски складно коегзистирају дијалектизам ђевојка и покрајинска лексема јатка (Да се не обрукам пред јатком и ђевојкама 52, Јатка је још погледивала на крвнике и ђевојке 55). ${ }^{8}$ Ту су и покрајинске форме преманути (И премануло сунце 12), шкрб (На онај шкрби камен се наслонио 12), обурдати (Обурдали би је 21), наножити (Усправи као слину / Подрами и наножи 51), броћ и блуштур (Загрли бућор броћа и бљуштура 54), надостити се (А поготову наш / Који се властите крви / Не може надостити 113).

Додатни стилски ефекат Бећковић постиже кумулацијом локалне лексике, као у песми „Стид”, у којој је поетски активирао лексеме зера ('сасвим мало, трунчица'), пак, локум ('коцка'), цукар ('шећер'): Дала си ми зеру чеснице / Грам воска / Пак дувана / Прегршт ораха / Локум цукра / И котур смокава / Да однесем у шуму ономе несретнику (73).

Наравно, локализме је тешко одвојити од дијалектизама ако се држимо искључиво нормативних речника као критеријума за класификацију. Будући да је нема у PMC, а има у РСАНУ, лексема изргати ишла би, на пример, у дијалектизме: Једва се устежући да је не споврљамо / И изргамо га сами (38). ${ }^{9}$ Многе Бећковићеве лексеме РМС и РСАНУ и не бележе: освинути (Али ако би ме икад осенио / И игде освинуо 15), громбосан (Све је и без њега громбосано 25), гувежљати се (Залуду се гувежљаш

8 Лексема јатка одређена је у РМС на следећи начин: покр. јадница, сиротица (као израз сажальеьа).

9 У значењу „извадити, избацити” (РСАНУ). 
и натежеш 40). До других које су непотврђене у РМС, опет, РСАНУ још није стигао у објављеним томовима: ћутни (До ћутне минуте 32), споврљьати 38, пробечити 63, премученица 74, тутати (Сву ноћ смо тутали уз оне кукове 80). Треће, пак, данас нису честе иако немају никакав квалификатор у РМС: изновице (Па ако јесам причаћу изновице 33), гундорити (Гундорећи да не би смела тако 38), ${ }^{10}$ тојага 32, убилаи, 108, и сл.

Исту стилску функцију дочаравања исказа карактеристичних за веома јасно дефинисан простор, као и карактера њихових твораца, имају и лексема (речца тј. узвик) ела (Ела / Немој заборавити 10), одређена у РМС као „покр.", именица самохраница (Не прима плату на сирочад и удовице / Ни пензије ни самохранице 97), наведена без квалификатора, ${ }^{11}$ као и именице чоче (Мој Љубица / Мој посмрче / Наш свих мука / Женски чоче 82) и рђ (А шта да изгори / Сем рђа и чађа 21), којих у РМС нема. Сличан призвук има и прилошка конструкција по юеговски, такође потврђена у РМС: Да размане по његовски (24). ${ }^{12}$ Додатну евокативну функцију имају поједине лексеме које такође циљају на препознавање одређеног простора и његове културе, али нас додатно подсећају и на Вуково и Његошево стваралаштво: рашта (И прегнути нешто / Да се има рашта 19), ками (А ками смо изгубили 20), свашто (У младости спремни на свашто 45).

Сасвим у духу ровачкога говора јесте лексема темељковић из песме „Ниси ти више мали”: Чему се смејеш / Мој темељковићу (59), Не доликује теби да се смејеш / Мој темељковићу (64). Ову лексему РМС не

10 У значењу „мрмљати” (РМС се овде позива на Вуков Српски рјечник).

11 Именица је илустрована само једним примером, тематски повезаним са Црном Гором.

$12 \mathrm{У}$ дијалекатским поемама потврђен је и облик њински (Петровић 2003: 150). 
бележи, а нема је ни у „Речнику уз књиге Рече ми један чоек, Међа Вука Манитога, Леле и куку" (Петровић 2003). У овоме речнику, међутим, налазимо лексеме горојевић, неранимајковић, нечуловић, никоговић, ничеговић, танкодушић, трокапић, чеговић, грађене по истом творбеном принципу којим се стварају именице налик на презимена. Границе између локалног и песниковог овде се свесно бришу јер се и са̂м песник приклања колективу: „Многе су речи настале у говорноме стваралаштву, само за једну прилику - тако да у контексту значе све, ван њега ништа" (Бећковић 2003: 165). Тако и према именици nоштенбаша из дијалекатских поема (Петровић 2003: 161) у књизи Хлеба и језика стоји парадигматска именица поштенбрат: Лежаћеш довољно / Поштенбрате (60). Грађена је према моделу који из значењског угла најбоље одсликава дух једнога колектива.

После прегледа дијалекатске и локалне лексике у збирци Хлеба и језика остаје отворено питање да ли би и ову књигу требало да прати одговарајући речник мање познатих речи. Њих је неупоредиво мање но у дијалекатским поемама, али бројне лексеме ипак стварају комуникативни шум читаоцима из савремених градских средина, нарочито на екавској територији. ${ }^{13}$

4. Колоквијализми и опонашағе (раз)говора. У тежњи ка максималној актуелизацији, ка натуралистичком опонашању сасвим конкретног резултата живога (раз) говора, Бећковић посеже и за колоквијалним облицима, попут лексеме пешестина из песме „Долазак”: Стајала је њих пешестина код цркве (12). Међу колоквијализме би се, иако је дат у РМС без квалификатора, могао сврстати

13 Овде ваља обратити пажњу и на важно теоријско-методолошко упозорење: „Тешко је правити речнике Бећковићеве поезије, поготово ако се има на уму да једна ријеч има сасвим друго значење изван те поезије, нарочито у другом крају, изван Роваца" (Делић 2012: 21). 
и глагол крампати (Зато ми је лакше да кулучим и крампам 29). ${ }^{14}$ Разговорна конструкција чек чек у игри речи мотивише грађење неологизма недочек у песми „Хлеба и језика": А оно чек чек / Па чек недочек (19).

5. Вулгаризми и бег од радикалне експресивности. Вулгаризми као изразито радикално средство експресивности нису честе стилеме у Бећковићевој поезији, па их је и у књизи Хлеба и језика готово немогуће потврдити. У ову лексичку категорију морали бисмо сврстати само лексему nuшаћа (И нестах у прашини као кокошиња пишаћа 54), наведену у РМС са квалификатором „вулг., уз позивање на Вуков Српски рјечник. Вулгаризми са опсценом компонентом очито су Бећковићу у поезији потпуно страни.

6. Архаизми као дискретан стилски зачин. Уколико по страни оставимо поједине дијалектизме и локализме који се из савремене комуникације полако али сигурно повлаче под ударима глобализације, ${ }^{15}$ других архаизама готово да и нема у Бећковићевој књизи Хлеба и језика. На пример, глагол подрамити, грађен сасвим у народном духу, потврђен је у РМС само примером из Вуковог Српског рјечника, а код Бећковића у песми „Који је оно, мајко?”: Усправи као слину / Подрами и наножи (51). Глагол забрижити се, потврђен у РСАНУ само једним примером Ђуре Јакшића, васкрсава у Бећковићевој песми „Трорука чудотворка": Горела је Света Гора / Забрижио се свет (103).

Са квалификатором арх. морала би се могла навести и форма именице целиваније, са црквенословенским

14 Занимљиво, именица крамп одређена је у РМС као „нем. покр.”, док уз глагол крампати не стоји ниједан квалификатор.

15 Тачно је запажање: „Активирањем дијалекта пјесник је пробудио и у свој пјеснички језик унио старије, готово изгубљене, у сваком случају за књижевност 'заспале' језичке слојеве; активирао је заспали, привидно угашени језички вулкан, и то не само на лексичком, већ и на синтаксичком, а нарочито на фразеолошком плану” (Делић 2012: 27). 
суфиксом -ије, из песме „Везивање за мрца”: Као последње целиваније (125). Архаичан је и русизам расказати (РМС: 'испричати, исприповедати; објаснити'), активиран, уз асоцијацију опет на Његоша, у игри речи из песме „Био је смак света": А Благовести / Скази расказани (123). Именица звежђе наведена је у РМС, али без примера. Бећковић је употребљава у песми „Милош Обилић”, у којој евоцира време Косовског боја: Цара чија се чалма свијала међу звежђем (86). Ретка је данас и именица пожарник, потврђена у Речнику српскохрватског книжевног језика Луја Бакотића и одатле пренета у новије речнике, као и именица чудевство из истох стиха песме „Трорука чудотворка": Пожарници су се мрзли пред чудевством (104).

7. Неологизми као средство ироније. Само у песми „Милош Обилић” Бећковић је најавио нови песнички поступак који ће у потпуности остварити у потоњим збиркама - активирање неологизама као кривог огледала модерног света. Сукоб лепше прошлости у ружне савремености у песми „Милош Обилић” илуструју лексеме које су само привидни анахронизми: маркетинг (Како саветује маркетинг за издају 85), скенер и дигитрон (Провлачили испод копита и сабљи / Како су се онда звали скенери и дигитрони 86). Продор нових лексема у српски језик, нарчито путем модерних језичких контаката, постаће касније повод за нове песничке дијалоге са нестандардним идиомима. ${ }^{16}$

8. Семантичка прозирност индивидуалних неологизама. Бећковићев језик карактеришу бројни индивидуални неологизми, и ту сопствену поетичку традицију он је само наставио у збирци Хлеба и језика. Као један од песника склоних аутопоетичким исказима у пое-

16 У књизи Кад будем млађи „истраживање у језику усмерено је на говор младих, на субстандард пун туђица и варваризама" (Делић 2012: 28). 
зији, Бећковић нам стално пружа могућност вишеслојног тумачења његових песама. Тако се и читава песма „Крушка”, са уводним стиховима који нас не воде одмах на прави траг (Време је да испричам / Како смо брали крушку / Крушку батињачу / Што је расла уз сами пут / И рађала као воћке на путу 41), може читати и као прича о узроцима губљења имена и мотивацији за ново именовање, односно као прича о архаизацији и неологизацији: По кори и листу / Била је то крушка браница / А по плоду дивљака / Која се помамила међу нама / За својим родом / И кренула да буде трн / Тако јој се и име затурило / А замлаћена и обезграњена / Швргава и одрпана / Задивљана и тучом изјаловљена / Прозвана је батињача (42). ${ }^{17}$

Свету у којем речи брзо нестају и настају Бећковић прилаже значајан лексикотворни додатак, кујући неологизме прозирног значења и велике експресивности и сугестивности, углавном налик на постојеће лексеме из народног језика. ${ }^{18}$ Тиме се уклапа у значајан поетички ток српске књижевности, не само савремене, дајући истовремено специфични индивидуални допринос процесу стварања нове песничке лексике.

8.1. Специфичност Бећковићевог лексикотворства, између осталог, представља и често грађење новоскованих глагола, што други српски песници неупоредиво ређе чине. Само у песми „Псуј мене” песник ствара напоредни низ глаголских неологизама - дошенширати, задомаћи-

17 Језик је Бећковићева опсесивна тема и ван саме поезије, примећује и Петар Пијановић (2012: 55): „По свему се види да у својим поетичким разматрањима, која су садржана у Беседама, Матија Бећковић посвећује језику дужну и велику пажњу”. О језичкој самосвести и аутопоетичким тренуцима још и у Делић 2012.

18 Бећковићев аналошки принцип у творби индивидуалних неологизама Миодраг Матицки (2012: 77) описује као процес којим песник гради „нове речи, логички изведене”, оцењујући га као „мајсторлук језикотворства”. 
нити се, окомотити се, замрштити се, затрбушити се: Ко зна одакле си дошенширао / У мојој се кући задомаћинио / Окомотио и замрштио / С братске крви затрбушио (95). Само у једној кованици Бећковић је на директном трагу народног и стандардног језика јер од глагола задомаћити се (РМС: 'постати домаћин, домаћица') изводи глагол прецизније семантике - задомаћинити се.

Посебно су међу новоскованим глаголима ефектне експресивне сложенице из песама „Који је оно, мајко?” и „Јеја”: ломовраћати се (Па се опуштених руку и постиђених леђа ( У навод сунца ломовраћала кући 55), костоломити и вратоломиюати (Сву ноћ смо тутали уз оне кукове / Подизали се и падали / Костоломили и вратоломињали 80).

Само са основом језик- у збирци су два неологизма јасне мотивације и семантике: разјезичити у песми „Ђе рече Јапан” (Не дам да ми кидишу на језик / И да ме разјезиче 29) и језикати у песми „Псуј мене” (А ти језикаш и ореш лобањишта 96). У другима се, опет, тешко назире и једно и друго, као у глаголу ћићикнути (Неко те и за ту лаву налокао / Ћићикнуо и надрашкао 98).

Ефектне резултате Бећковић је постигао и префиксацијом глагола, творећи глаголе налик на постојеће, али ипак нове, са прецизираном семантиком. Такви су глаголи уризикати из песме „Долазак” (Није се уризикало 14) и запрашинати из песме „Који је оно, мајко?”: С мање висине бих упирио на врх мозга / И запрашинао у шодер и камење (53). Суфиксацијом је пак добијен глагол завапијати из песме „Ђе рече Јапан”: Али и он је ту скоро завапијао (32). Аналошки је изграђен глагол обездетити, а модел је сасвим јасан већ из најближег контекста у песми „Пас”, у којој се већ у наредном стиху јавља постојећи глагол обезбратити (РМС: 'остати без брата'): Ти моје обездетио / Ја твоје обезбратио (110).

8.2. У односу на глаголе, новоскованих придева и прилога неупоредиво је мање. Међу придевима пажњу 
привлачи сложеница неболик из песме „Кокошка”: Тако се најављивало и неболико јаје (37). Иако је овај придев потврђен једним примером Аугуста Шеное у РМС (Јаки су сводови били бојадисани плаветном, неболиком бојом), он се може сматрати и Бећковићевом кованицом, jep је тешко утврдити његове поетичке и друге везе са A. Шеноом. Изненађујући новосковани прилог натенански изграђен је од колоквијалног прилога турског порекла, са јасном иронијском компонентом: С крушке одгризали зелену рану / А остатак отуцали натенански (43). Према прилозима типа кучећи (нпр. Пливати кучећи, тј. 'налик на куче, попут кучета'), Бећковић гради прилог штенећu, који пуно значење добија у песми „Јунак и кучка”: Окренула се зиду докле прође / Али се Симо Кучка заустави / И с капом у руци именом је зовну / А заносио је помало штенећи (79).

8.3. Као и код других српких песника, велики број кованица су именице. Модели њихове творбе различити су, почев од извођења, преко слагања и комбиноване (сложено-суфиксалне) творбе, до срастања речи у лексичке конструкције, попут облика чавка-удовица (На њу је слетела / Чавка удовица 68, Које више не говоре / Чавке-удовице 69).

8.3.1. Као и у српском језику, и у Бећковићевом изразу код нових именица доминирају бројем оне изграђене суфиксацијом: тетиљанција (Све тетиљанције и побркотине 30), побркотина (Све тетиљанције и побркотине 30), осамник (Као бор осамник 33), безглавија (У безглавији иза рата 68), ${ }^{19}$ лажавина (За твоје владавине и лажавине 97), ${ }^{20}$ пашчарница и лавежница (Права кучка то никад не би лајала / Ни у каквој пашчарници и лавеж-

19 РСАНУ бележи Крлежину кованицу безглавље готово исте семантике.

20 Из контекста је лако уочљиво уопштавање творбеног модела. 
ници 97). Поједине изведенице као да покрећу скривене дијалоге међу савременим српским књижевницима, па именица лобағиште из песме „Псуј мене” (А ти језикаш и ореш лобањишта 96) остварује суптилне корелације са прозним стваралаштвом Мира Вуксановића у којем су сличне изведенице веома честе, препознатљиве и ефектне (Милановић 2018), а именице усмртило и опачило из песме „Везивање за мрца” (Од свих усмртила / Мучила и опачила / Најтеже су турске муке 124) са поезијом Новице Тадића, у којој се јављају сродне изведенице блиске семантике (Милановић 2016б).

8.3.2. Попут сложеница међу придевима, и нове именице добијене комбинованом творбом имају повишену експресивност у односу на нове изведенице: злорек (Зазидај уши / За злорек из брза грла 77), ${ }^{21}$ неботик ( И тада је звизнуо рез - неботик 87), ${ }^{22}$ браћождерство (Од судњега дана / Да је непогода / Од браћождерства / Преврат и слобода 123) 23 .

И у овој књизи Бећковић је наставио традицију грађења нових „императивних сложеница”, по начину творбе типичних за српски народни језик: плетиприча и плетипричалица (Тобож слушају плетипричу / Плетипричалица 31), смлатимозговица (По летњој смлатимозговици 50). Овај тип сложеница, сведочи не само речник лексема из дијалекатских поема (Петровић 2003), веома је карактеристичан за Бећковићеву поезију (Милановић 2012).

9. Необични лексички спојеви и разбијағе колокација. Ефектност активиране лексике огледа се не само на оси селекције, где смо видели да песник захвата из различи-

21 Исту именицу, али са другачијим значењем, 'који је брз на злу реч’ потврђује РМС у делу Иве Андрића.

22 Као својеврстан творбени и звуковни пандан овој именици са првим елементом неб- стоји наведени придев неболик.

23 Аналогија са именицом људождерство је више него очигледна. 
тих извора, већ и на оси њене комбинације. Почев од наслова збирке, Бећковић свесно разграђује колокације, па се уместо очекиване напоредне конструкције Хлеба и игара појављује нова, која сав фокус баца управо на новоизабрану, неочекивану реч. Уџбенички пример може бити и синтагма једнособни свет из песме „Кокошка”: Тако су у једнособном свету / С највећим очима и ушима / Живели заједно људи и живина (39).

10. Закључак. Збирком Хлеба и језика Матија Бећковић потврдио се као један од највећих живих уметника речи у српској поезији. Бројне стилске поступке пренео је из претходних књига у ову, обогативши при томе свој песнички лексикон новим обележеним јединицама у различитим скупинама (дијалектизми, локализми, колоквијализми, вулгаризми, архаизми, неологизми), али је наговестио и одређене поступке који су допринели увођењу посве нове и другачије лексике у потоње збирке, као и сасвим нови песнички однос према непесничком језику који нас окружује.

\section{ИЗВОР}

Матија Бећковић, Хлеба и језика, Сабране песме у девет књига, књига девета, Београд: Српска књижевна задруга, 2003.

\section{ЛИТЕРАТУРА}

Бећковић 2003: Матија Бећковић, „Белешка”, у: Матија Бећковић, Рече ми један чоек, Сабране песме у девет књига, књига трећа, Београд: Српска књижевна задруга, 161-168. Делић 2012: Јован Делић, „Аутопоетички тренуци Матије Бећковића - језичка самосвијест", у: О песмама, поемама 
u поетици Матије Бећковића (ур. Јован Делић и Драган Хамовић), Београд - Требиње: Институт за књижевност и уметност - Учитељски факултет Универзитета у Београду - Дучићеве вечери поезије, 17-48.

Матицки 2012: Миодраг Матицки, „Естрадно-ораторско-реторичка страна поетике Матије Бећковића”, у: О песмама, поемама и поетици Матије Бећковића (ур. Јован Делић и Драган Хамовић), Београд - Требиње: Институт за књижевност и уметност - Учитељски факултет Универзитета у Београду - Дучићеве вечери поезије, 67-81.

Микић 2012: Радивоје Микић, „Карневализација у поемама Матије Бећковића", у: О песмама, поемама и поетици Матије Бећковића (ур. Јован Делић и Драган Хамовић), Београд - Требиње: Институт за књижевност и уметност Учитељски факултет Универзитета у Београду - Дучићеве вечери поезије, 83-122.

Милановић 2010: Александар Милановић, „Бећковићева дијалекатска поезија и стилистичка норма”, у: Језик српских песника, Београд: Завод за уџбенике, 161-172.

Милановић 2012: Александар Милановић, „Бећковићев поетски опус као ресурс за истраживање сложеница са инфиксом -и-", Научни састанак слависта у вукове дане, 41/3, 193-209.

Милановић 2016а: Александар Милановић, „Иза језичке игре у Бећковићевој поеми Ћераћемо се још", у: Реч под окриљем поетике : Језик српских песника 2, Краљево, 119-141.

Милановић 2016б: Александар Милановић, „Тадићеви индивидуални неологизми са суфиксом -ло", у: Реч под окрилем поетике : Језик српских песника 2, Краљево, 177-194.

Милановић 2018: Александар Милановић, „Од речишта до речничишта у 'Семољ гори' Мира Вуксановића', у: Савремена српска проза, 30, Трстеник: Народна библиотека „Јефимија”, 2018, 69-84.

Палавестра 2012: Предраг Палавестра, Послератна сриска књижевност 1945-1970 и юена историја, Београд: Службени гласник.

Петров 2012: Александар Петров, „Матија Бећковић - књи- 
жевна биографија", у: О песмама, поемама и поетиии Матије Бећковића (ур. Јован Делић и Драган Хамовић), Београд - Требиње: Институт за књижевност и уметност Учитељски факултет Универзитета у Београду - Дучићеве вечери поезије, 467-496.

Петровић 2003: Драгољуб Петровић, „Речник уз књиге Рече ми један чоек, Међа Вука Манитога, Леле и куку”, у: Матија Бећковић, Леле и куку, Сабране песме у девет књига, књига пета, Београд: Српска књижевна задруга, 103-193.

Пијановић 2012: Петар Пијановић, „Поетички погледи Матије Бећковића", у: О песмама, поемама и поетици Матије Бећковића (ур. Јован Делић и Драган Хамовић), Београд Требиње: Институт за књижевност и уметност - Учитељски факултет Универзитета у Београду - Дучићеве вечери поезије, 49-65.

Радуловић 2012: Марко Радуловић, „Искушења говора - пародија и парадокси Матије Бећковића", у: О песмама, поемама и поетиич Матије Бећковића (ур. Јован Делић и Драган Хамовић), Београд - Требиње: Институт за књижевност и уметност - Учитељски факултет Универзитета у Београду - Дучићеве вечери поезије, 203-229.

РМС 1967-1976: Речник српскохрватскога књижевног језика, 1-6, Матица српска (- Матица хрватска), Нови Сад (Загреб).

РСАНУ: Речник српскохрватског книжевног и народног језика, 1-20, Београд: Институт за српски (српскохрватски) језик САНУ, 1959-2017. 
Aleksandar Milanović

\section{STYLISTICALLY MARKED LEXIS IN THE COLLECTION OF POEMS HLEBA I JEZIKA BY MATIJA BEĆKOVIĆ}

\section{Summary}

The paper analyzes stylistically marked lexemes such as dialectisms, localisms, colloquialisms, vulgarisms and neologisms which appear in the collection of poems entitled Hleba i jezika by Matija Bećković. The focus of analysis lies on the frequency and function of such marked lexemes. In addition, we define the position of a lyrical subject, a narrator, and compare it against his poetic expression while establishing correlations among the analyzed lexemes.

Key words: marked lexemes, poetic language, poetic lexis, symbol, cumulation, dialectisms, colloquialism, vulgarisms, neologisms. 